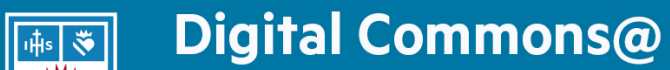

Loyola Marymount University

LMU Loyola Law School

Journal of Catholic Education

\section{"Déjà vu All Over Again": Commentary on the Catholic Higher Education Collaborative Conference on Leadership at Loyola University Chicago}

Merylann J. Schuttloffel

Follow this and additional works at: https://digitalcommons.Imu.edu/ce

\section{Recommended Citation}

Schuttloffel, M. J. (2010). "Déjà vu All Over Again”: Commentary on the Catholic Higher Education

Collaborative Conference on Leadership at Loyola University Chicago. Journal of Catholic Education, 14 (1). http://dx.doi.org/10.15365/joce.1401072013

This Focus Section Article is brought to you for free with open access by the School of Education at Digital Commons at Loyola Marymount University and Loyola Law School. It has been accepted for publication in Journal of Catholic Education by the journal's editorial board and has been published on the web by an authorized administrator of Digital Commons at Loyola Marymount University and Loyola Law School. For more information about Digital Commons, please contact digitalcommons@lmu.edu. To contact the editorial board of Journal of Catholic Education, please email JCE@nd.edu. 


\title{
"Déjà vu All Over Again": Commentary on the Catholic Higher Education Collaborative Conference on Leadership at Loyola University Chicago
}

\author{
Merylann J. Schuttloffel
}

The Catholic University of America, Washington, D.C.

$\mathrm{I}$

n 1960, while I sat in my fifth grade classroom, was anyone thinking about the potential catastrophic events that would turn the Catholic Church and Catholic schooling into a proverbial tailspin for the next 50 years? At that time the Benedictine Sisters provided all the educational leadership for my grade school with one exception: My fifth grade teacher, a married lay woman, had abandoned public school teaching to donate her time to the parish grade school. Mrs. Day and the Benedictine Sisters were minimally compensated for their teaching and there was no significant tuition except the occasional special collection on Sunday. The entire parish supported the school financially, as everyone was strongly encouraged to attend. This was the typical scene in Catholic parishes across the country at that time. The familiar parish model remained unchanged for 100 years.

Then larger historical events began to impact the parish school: John F. Kennedy was elected president of the United States and Pope John XXIII convened the Second Vatican Council. American Catholics were accepted as good citizens and became more financially secure outside their ethnic ghettos (Dolan, 2002; Gibson, 2003; O'Toole, 2008). American Catholics became part of the cultural mainstream. Some individuals went so far as to suggest that Catholic schools were an antiquated concept in light of Vatican II (Ryan, 1964). Over the decades a parochial school seemed inappropriate for more and more assimilated Catholics. At the time did anyone question the parish school model's viability? "If it isn't broken, don't fix it" was a default adage. Eventually, Catholics and Catholic schools parted ways. The intersection of student enrollment demographics, diminished religious congregation num-

\footnotetext{
1 Yogi Berra explained that the quote, "It's déjà vu all over again" originated when he witnessed Mickey Mantle and Roger Maris repeatedly hit back to back home runs in the Yankees' seasons in the early 1960 s.
}

Catholic Education: A Journal of Inquiry and Practice, Vol. 14, No. 1, September 2010, 107-113 C Trustees of Boston College. 
bers, and strained parish financial reports frame the Catholic school crisis that continues today (Youniss \& Convey, 2000).

The 1970s was a decade lost to disbelief and disorder. Whatever had stabilized Catholic schooling in the past was weakened. Diminished numbers in the various teaching religious congregations opened the door to lay teachers who wanted to serve the Church (Przygocki, 2004). Lay teachers were formed teaching side by side with the remaining religious. In addition, schools were staffed by the former religious who remained loyal to their educational vocation. So while there was a vacuum, there was also a new hopefulness fueled by Church documents that highlighted the role of the laity.

But by the 1980s my own experiences in the Midwest and southern states were evidence to a steadily decreasing number of religious in school leadership positions. Lay leadership was on the rise and it was clear that lay school leaders required a more formalized preparation if they would maintain the Catholic identity within the schools. The Association of Catholic Leadership Programs (ACLP) was the product of the intersection of Catholic higher education and the needs of K-12 schooling. Encouraged by the National Catholic Educational Association (NCEA), the ACLP, founded in 1983, aggressively worked to develop, standardize, and support the preparation of school leaders through its collegial network. Recently, the ACLP changed its name to Catholic Higher Education Supporting Catholic Schools to emphasize its broad commitment to pre-K-12 schooling beyond leadership preparation.

The preparation process was greatly enhanced in the 1990s with the publication of Ciriello's $(1993,1994,1996)$ leadership formation tripartite. These texts institutionalized the key competencies for management, instructional, and spiritual leadership. This valuable contribution to the curriculum for leadership formation programs provided definitions for the knowledge and skills required for Catholic school leadership.

Following further analysis of the growing body of leadership research, the Chief Administrators for Catholic Education (CACE) department of NCEA commissioned a monograph series dedicated to fleshing out leadership competencies further within the Catholic school context. The first volume focused on the vocation of the Catholic educator (Jacobs, 1996). Over the next decade these monographs highlighted leadership research and Church documents as applied to the Catholic school context (Cook, 2001; Schuttloffel, 1999).

In 2001 a symposium was convened at the University of San Francisco for the purpose of bringing together members of K-12 leadership, Catholic higher education, the NCEA, and Catholic Conference of Bishops. The focus of the symposium was to address the impending shortage of Catholic school leadership and teachers. A follow-up symposium was held at the University 
of Dayton the following summer (Schuttloffel, 2003a). One result of the two conferences was the commissioning of a research study for fact finding about the state of the principalship (Schuttloffel, 2003b). The results of that study highlighted the weak linkage between Catholic higher education and the actual preparation of Catholic school principals. While there was a wide number and variety of Catholic leadership programs, a high percentage of Catholic school principals did not receive their leadership preparation from those programs (Schuttloffel, 2003b).

Again during the efforts to create a strategic plan for the NCEA, leadership preparation received attention and became a critical recommendation (NCEA, 2004). Into this environment arrived the University of Notre Dame report, Making God Known, Loved, and Served: The Future of Catholic Primary and Secondary Schools in the United States (Notre Dame Task Force on Catholic Education, 2006). One recommendation coming out of the task force was to enlist the help of Catholic institutions of higher education (CIHE) in support of Catholic schools and to increase related research by expanding the "field of Catholic education." Following a conference in response to this recommendation, cohosted by the University of Norte Dame and the Carnegie Institute for the Advancement of Teaching in fall 2007, nine Catholic colleges and universities began a collaborative process to explore ways CIHE could increase effective support of pre-K-12 Catholic schools. This new organization, Catholic Higher Education Collaborative (CHEC), committed to hosting a series of six conferences focused on forming partnerships to generate innovative responses to the critical nature of the current state in Catholic schooling. The Loyola University Chicago CHEC conference on leadership in October of 2009 was the second in the series.

Consequently, in October 2009, from my far-away sabbatical location, I tried to imagine what I was missing at the Loyola leadership conference. How would this gathering be different from all the meetings, symposia, and conferences held in the past decade that addressed Catholic school leadership? The image of rearranging the deck chairs on the Titanic came to mind: Clearly, doing the same old things was not going to work.

Research exists that elaborates the significance of leadership when addressing Catholic school viability (DeFiore, Convey, \& Schuttloffel, 2009). Attempts at collaboration between Catholic higher education and Catholic schools offices continue. The CACE annual conference has provided a setting for idea and practice exchange. But oftentimes the dynamic is either productive or not due to an individual institution's personnel and personalities. The relationship between Catholic higher education and pre-K-12 Catholic 
schooling should be a priority encouraged by the local bishop and supported and encouraged by the superintendent.

So, what is new now? There is little to argue with in the five proposed follow-up initiatives or areas for work created at the Loyola conference, but here are a few bits of déjà vu commentary.

\section{Creation of Standards for "Essential Catholic Schools"}

The concept of national standards for Catholic education has the potential to offer some guidance to the challenge of defining what makes a school Catholic. Having spent considerable time exploring this topic nationally and internationally, I might add that there are some clues on how to proceed with this endeavor. Currently there are (arch)dioceses that have developed a framework with standards as part of their individual state accreditation processes. My suggestion would be to explore the relationship between these accreditation requirements and the national standards for the sake of coherency. One thing that has been learned by agencies that deal in standards: Fewer are better. There is a tendency to overdefine and regulate within the public educational sector. One strength of Catholic schooling has been its sleek bureaucratic operation (I know, that is code for understaffed!) and the principle of subsidiarity. We do not want to imitate the mistakes of government schools and their entrenched, fossilized bureaucracies.

\section{Redesign and Expansion of Higher Education Leadership Programs to Meet the Needs of the Contemporary Context}

There is always room for improvement within principal preparation programs, but I believe the focus must shift to include the preparation of classroom teachers with the same intensity that Catholic higher education attacked principal leadership programs 25 years ago. Money is a big deterrent to teaching in Catholic schools. After completing a teacher preparation program at a Catholic college or university there are often significant student loans. I have heard the criticism from our former students. They know that we have excellent undergraduate programs, but without financial support, future Catholic school teachers cannot afford it. Catholic higher education needs to become part of the solution and it will cost money. I am not naïve about how much higher education costs, but perhaps some creative development programs at the university level could bring support from alumnae that recognize the value of their Catholic school experience and make a commitment to pass that on to the next generation. One critical source of future Catholic school leaders rests in attracting and retaining outstanding Catholic school teachers. 
I would love to see Catholic higher education tuition benefits for high school students who commit to teach in Catholic schools. Perhaps a loan payback program for time served. Or perhaps incentives for the children of Catholic school teachers to attend Catholic colleges and universities. These are not new ideas, but their implementation demonstrates a commitment to pre-K-16+ Catholic education.

At the undergraduate level we can do much better in our efforts to prepare Catholic school teachers. Our department has made Catholic school teacher preparation a priority in the next 5-year plan. I commend the universities that developed the ACE program and other service corps programs for recognizing a need and responding.

\section{Design and Implementation of a "Resource Cloud"}

This is a very clever idea, something that technology can facilitate. And I would offer that if we cannot figure out how to do it, we could recruit some young teachers and high school students who have the technology literacy to get it done. Fresh knowledge that is the result of collaboration between higher education and practitioners is what will keep the cloud attractive.

\section{Creation of a National Agenda for Expanding and Disseminating Research on Catholic Education}

At this year's American Educational Research Association conference the Catholic Education Special Interest Group made its debut. This event gives professional legitimacy for the discipline within the larger educational research realm. While many insiders would argue that there has been a discipline of Catholic education since the 13th century, the explicit validation from the larger educational research field is important for those scholars at Catholic institutions who would like to pursue the discipline as part of their promotion and tenure process. This is an example of why support of the only Catholic scholarly journal in the United States, Catholic Education: A Journal of Inquiry and Practice, is so important. The journal is moving to an open access format to help disseminate and expand the research to a broader, global audience, further advancing research on Catholic education. There needs to be a realization within pre-K-12 Catholic education that we are all on the same ship, either the Titanic or the Princess Star. The fate of Catholic higher education and its distinctive mission is in jeopardy if Catholic schooling withers. 


\section{Creation of a National Think Tank on Catholic Education}

This recommendation could be merged with the previous topic. In my opinion, educational research only adds pages to my curriculum vitae if it makes no contribution to the practitioner in the field. Many of my colleagues in Catholic higher education shared years in the schoolhouse before moving to the ivory tower. We recognize the importance of connecting our research to the field. One area for further research includes what can we learn from the various new school models, including the NativityMiguel and Cristo Rey schools, and what Catholic higher education can do to assist in developing more models. At various Catholic colleges and universities there are centers or institutes dedicated to Catholic educational research and professional development. A national think tank could be a natural extension of these in a unified, focused direction.

\section{Closing Remarks}

In closing I want to express my strong belief that the crisis Catholic schools face is larger than the insiders of the Catholic educational constituency. In fact, there is no solution that does not include increasing the perceived value of Catholic schooling at all levels in the hearts and minds of the larger Catholic and civic community. Valuable recommendations were generated at the Loyola leadership conference. President Michael Garanzini, S.J., Dean Dr. David Prasse, and Dr. Lorraine Ozar created an opportunity to challenge passive panic with creative thinking. The conference recommendations offer various imaginative means to extend a vision for the future of Catholic schooling. But, as in the past, the real progress to implement recommendations comes through strategies that direct the placement of resources and the commitment of individuals and groups. The core challenge of this conference-what holds the promise to move us beyond déjà vu-is whether we can shift the focus of problem-solving on behalf of Catholic schools from competition to deliberate and productive collaboration among CIHE and between CIHE and other stakeholders. Let us not just look back with dismay at the time lost, but consider today an opportunity to enhance the legacy of Catholic schooling. I am sorry I missed the conference, but count me in for the work ahead.

\section{References}

Ciriello, M. J. (Ed.). (1993). Formation and development for Catholic school leaders: The principal as educational leader. Washington, DC: United States Catholic Conference.

Ciriello, M. J. (Ed.). (1994). Formation and development for Catholic school leaders: The principal as managerial leader. Washington, DC: United States Catholic Conference. 
Ciriello, M. J. (Ed.). (1996). Formation and development for Catholic school leaders: The principal as spiritual leader. Washington, DC: United States Catholic Conference.

Cook, T. J. (2001). Architects of Catholic culture: Designing and building Catholic culture in Catholic schools. Washington, DC: National Catholic Educational Association.

DeFiore, L., Convey, J. J., \& Schuttloffel, M. J. (2009). Weathering the storm: Moving Catholic schools forward. Washington, DC: National Catholic Educational Association.

Dolan, J. P. (2002). In search of an American Catholicism: A history of religion and culture in tension. New York, NY: Oxford University Press.

Gibson, D. (2003). The coming Catholic church: How the faithful are shaping a new American Catholicism. New York, NY: HarperSanFrancisco.

Jacobs, R. M. (1996). The vocation of the Catholic educator. Washington, DC: National Catholic Educational Association.

National Catholic Educational Association. (2004). Centennial symposium participants explore roots of Catholic education before creating a vision for its future. Momentum, 35(2), 9-17.

Notre Dame Task Force on Catholic Education. (2006). Making God known, loved, and served: The future of Catholic primary and secondary schools in the United States. Retrieved from the University of Notre Dame Alliance for Catholic Education website: http://ace.nd.edu/assets/2296/ tf_cover.pdf

O'Toole, J. M. (2008). The faithful: A history of Catholics in America. Cambridge, MA: Harvard University Press.

Przygocki, W. F. (2004). Review of research: Teacher retention in Catholic schools. Catholic Education: A Journal of Inquiry and Practice, 8(1), 523-547.

Ryan, M. P. (1964). Are parochial schools the answer? Catholic education in the light of the council. New York, NY: Holt, Rinehart \& Winston.

Schuttloffel, M. J. (1999). Character and the contemplative principal. Washington, DC: National Catholic Educational Association.

Schuttloffel, M. J. (Ed.). (2003a). Leadership, recruitment, formation and support explored during two summer meetings. Momentum, 34(1), 46-49.

Schuttloffel, M. J. (2003b). Report on the future of Catholic school leadership. Washington, DC: National Catholic Educational Association.

Youniss, J., \& Convey, J. J. (Eds.). (2000). Catholic schools at the crossroads: Survival and transformation. New York, NY: Teachers College Press.

Merylann J. Schuttloffel is chair of the Department of Education and the director of Catholic Leadership at the Catholic University of America as well as a governing board member of the journal. Correspondence concerning this article should be sent to Dr. Merylann J. Schuttloffel, The Catholic University of America, 212 O'Boyle Hall, Cardinal Station, Washington, DC 20064. E-mail: schuttloffel@cua.edu 